\title{
New Record of Leucosiid Crab Nursia rhomboidalis (Crustacea: Decapoda: Brachyura) from Korea
}

\author{
Sang-kyu Lee ${ }^{1}$, Sung Joon Song ${ }^{2}$ and Won Kim ${ }^{1, *}$ \\ ${ }^{1}$ School of Biological Sciences, Seoul National University, Seoul 151-747, Korea \\ ${ }^{2}$ Department of Biology, Teachers College, Kyungpook National University, Daegu 702-701, Korea
}

\begin{abstract}
The leucosiid crabs are common species on soft sediment from the intertidal flat to shelf and slope depths. The genus Nursia Leach, 1817 is characterized by the pentagonal shape of the carapace and the presence of the buccal cavern on the pterygostomian region. As a result of the systematic study on the Korean brachyuran species, Nursia rhomboidalis (Miers, 1879) is newly recorded in Korean fauna. Korean Leucosiidae is now composed of 14 species belonging to eight genera. The description and illustrations of this species are provided.
\end{abstract}

Key words: new record, Nursia rhomboidalis, Decapoda, Korea

\section{INTRODUCTION}

The leucosiid crab known as nut crab or pebble crab is partly buried in the sediment at day and forages for preys at night. It can be found easily on soft sediment from the intertidal flat to shelf and slope depths (Schembri, 1982).

The genus Nursia Leach, 1817 has the pentagonal shape of the carapace and the buccal cavern on the pterygostomian region. Twenty species in genus Nursia have been known in the world ( $\mathrm{Ng}$ et al., 2008). However there has been no record on this genus in Korea so far. Recent inventory on the Korean brachyuran specimens revealed that several immature leucosiid female crabs of Nursia rhomboidalis (Miers, 1879) are collected from Yellow Sea, which are new record for Korean leucosiid fauna. Korean specimens of $N$. rhomboidalis are described and illustrated in the present paper. Korean Leucosiidae is now composed of 14 species belonging to eight genera.

The abbreviation "cl" refers to the carapace length from the frontal margin to the posterior dorsal margin. Drawings were made with the aid of a camera lucida. The specimens used in this study were deposited in the Marine Arthropod Depository Bank of Korea (MADBK), Seoul National University.

\footnotetext{
:To whom correspondence should be addressed

Tel: 82-2-880-6695, Fax: 82-2-872-1993

E-mail: wonkim@plaza.snu.ac.kr
}

\section{SYSTEMATIC ACCOUNTS}

Superfamily Leucosioidea Samouelle, 1819

Family Leucosiidae Samouelle, 1819

Subfamily Ebaliinae Stimpson, 1871

${ }^{1}$ Genus Nursia Leach, 1817

${ }^{2 *}$ Nursia rhomboidalis (Miers, 1879) (Fig. 1)

Ebalia rhomboidalis Miers, 1879, p. 42.

Nursia sinica Shen, 1937 , p. 279, figs. 1-2; Shen and Dai, 1964, p. 17.

Nursia rhomboidalis: Sakai, 1965, p. 39, fig. 5a-b; Takeda and Miyake, 1970, p. 219, fig. 5A-G; Sakai, 1976, p. 87, fig. 44a, b; Dai and Yang, 1991, p.67, fig. 30.

Material examined. 6 immature 우 우, (cl 3.57, 4.47, 4.62, $4.63,4.71$ and $11.46 \mathrm{~mm}$ ), Seokmun-myeon, Chungcheongnam-do, 11 Jul. 2007 (S. J. Song) by a van Veen grab $\left(0.1 \mathrm{~m}^{2}\right)$ Description. Carapace (Fig. 1A) almost pentagonal in shape, broader than long, and covered uniformly with fine granules; dorsal surface convex at center with four ridges extending forward, backward, left, and right; pterygostomian region (Fig. 1J) with buccal cavern and bearing tubercles along this cavern; hepatic region slightly convex; anterolateral border almost straight with some indistinguishable emarginations; epibranchial border with lobe of right angle; postero-lateral border behind epibranchial angle with two lobular outgrowths directed posteriorly and weakly downwards, distinctly separating from each other by wide concave; posterior margin in shape of semicircular lobe with

${ }^{1 *}$ 오각밤게속 (신칭), ${ }^{2 *}$ 오각밤게 (신칭) 


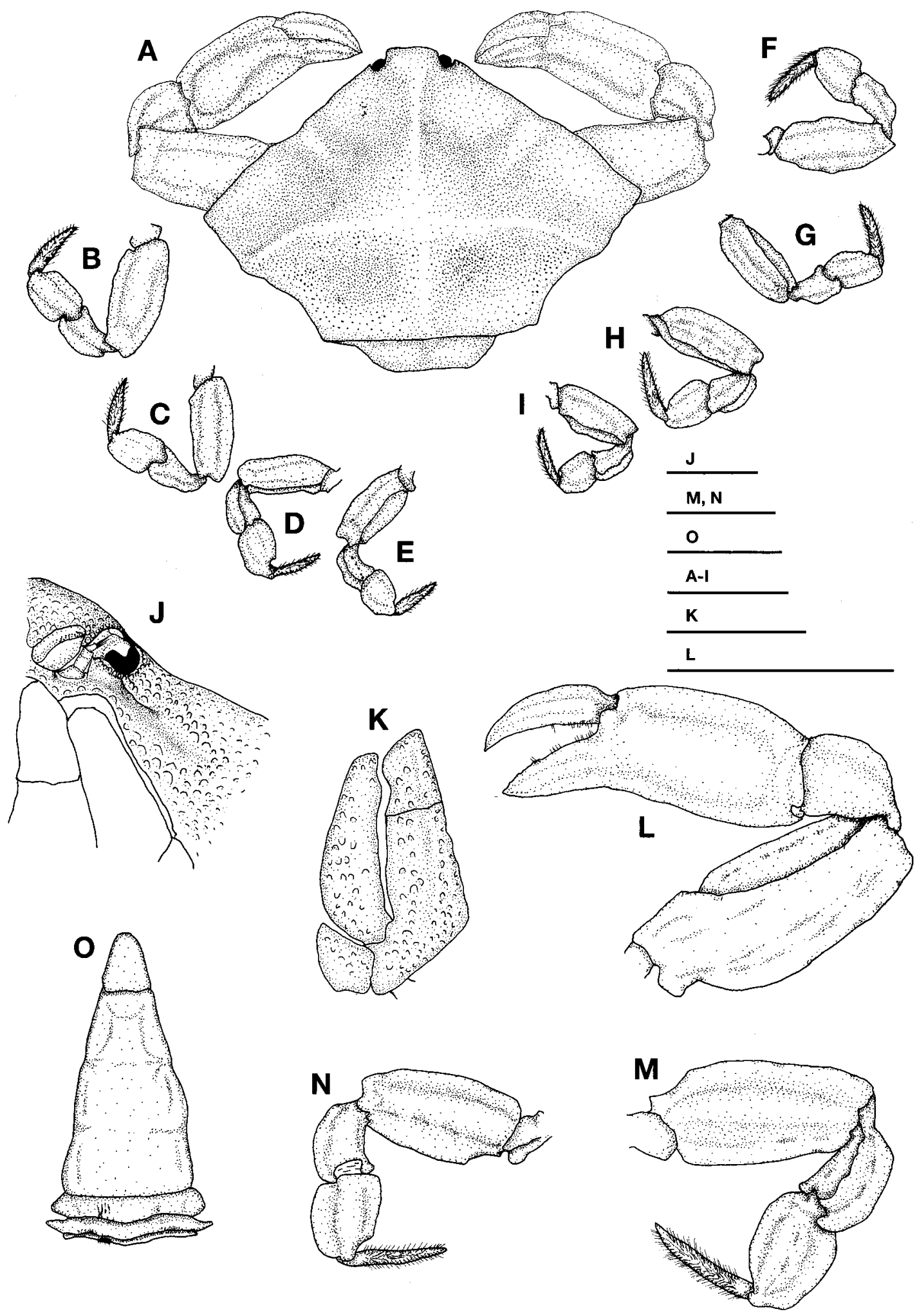

Fig. 1. Nursia rhomboidalis (Miers, 1879). Immature female. A, dorsal view of carapace; $B-C$, left 1st-2nd ambulatory legs, anterior view; D-E, left 3rd-4th ambulatory legs, posterior view; F-G, right 1st-2nd ambulatory legs, anterior view; H-I, right 3rd-4th ambulatory legs, posterior view; J, pterygostomian region, left side; $K$, left 3rd maxilliped; $L$, left cheliped; $M$, right 1 st ambulatory leg, posterior view; N, left 4th ambulatory leg, anterior view; O, abdominal segments. Scale bars=5 mm (A-I, L), $1 \mathrm{~mm}(\mathrm{~J}), 2 \mathrm{~mm}$ $(K, M, N), 3 \mathrm{~mm}(\mathrm{O})$. 
transverse ridge above near margin. Front broadly rounded in dorsal view, projected much beyond eyes. Orbit small and circular; anterior margin thickly granular; supraobital margin bearing two indistinct notches. Eyestalk short and protected by orbit. Antenna small. Third maxilliped (Fig. 1K) and sternum coarsely granulated.

Cheliped (Fig. 1A, L) about more than 1.5 times as long as carapace; outer surface of merus entirely flattened; dorsal and ventral border of merus sharply crested; outer border of carpus thin; dorsal and ventral border of propodus thin; dorsal border of propodus more convex than ventral one; cutting edges of fingers thin, finely toothed bearing proximal margin with setae on, with no gaping; movable finger slightly shorter than immovable finger.

Ambulatory legs (Fig. 1B-I, M-N) compressed; dorsal and ventral border of merus and propodus sharply carinate; dorsal border of carpus crested; posterior surface of carpus with longitudinal crest extending along whole length of segment; dactylus tomentose and coarsely granulated.

Immature female abdomen (Fig. 1O) consisting of five segments, fusing fourth to sixth segments; telson elongated triangle.

Remarks. According to the previous reports from Japan and China, Nursia rhomboidalis has two distinct notches on the supraorbital region and the postero-lateral border of its female carapace is almost straight (Shen, 1937; Sakai, 1965; Takeda and Miyake, 1970). However, the present immature female specimens show the following characteristics: notches on supraobital region indistinct; postero-lateral border of carapace bearing two lobular outgrowths distinctly separated from each other by wide concave; and lobe on epibranchial border less blunt.

The Japanese and Chinese specimens were collected at depth of $25 \mathrm{~m}$ to $35 \mathrm{~m}$ and at depth of $5 \mathrm{~m}$, respectively (Shen, 1937; Sakai, 1965). The Korean specimens were collected from sandy mud bottom at depth of $27 \mathrm{~m}$ around.

Distribution. Japan (coast of Kii Peninsula and Seto-Naikai), China (Jiaochou Bay), Yellow Sea of Korea (in this study).

\section{ACKNOWLEDGEMENTS}

This work was supported by a grant from the Eco-Technopia 21 project funded by the Ministry of Environment Republic of Korea and a grant from Marine Biotechnology Programme funded by Ministry of Land, Transport and Maritime affairs of Korean government.

\section{REFERENCES}

Dai, A.Y. and S.L. Yang, 1991. Crabs of the China Seas. Springer-Verlag, Berlin, Heidelberg, New York, Tokyo, pp. 1608.

Miers, E.J., 1879. On a collection of Crustacea made by capt. H. C. St. John R. N. in the Corean and Japanese Seas, Part I. Podophrhalmia. With and appendix by Capt. H. C. St. John. Proc. Zool. Soc. London, 1879: 18-61.

Ng, P.K.L., D. Guinot and P.J.F. Davie, 2008. Systema Brachyurorum: Part 1. An annotated checklist of extant brachyuran crabs of the world. Raff. Bull. Zool., 17: 1-286.

Sakai, T., 1965. The crabs of Sagami Bay, collected by his majesty the emperor of Japan. Muruzen co., Tokyo, pp. 1-92.

Sakai, T., 1976. Crabs of Japan and the adjacent Seas. Kodansha Ltd., Japan, pp. 1-773.

Schembri, P.J., 1982. The functional morphology of the feeding and grooming appendages of Ebalia tuberose (Pennant) (Crustacea: Decapoda: Leucosiidae). Jour. Nat. Hist., 16: 467-480.

Shen, C.J., 1937. Second addition to the fauna of brachyuran Crustacea of North China, with a check list of the species recorded in this particular region. Contr. Inst. Zool. Natn. Acad. Peiping, 3(6): 277-313.

Shen, C.J. and A.Y. Dai, 1964. Illustrations of animals in China (Crustacea part ii). Perking, pp. 1-172.

Takeda, M. and S. Miyake, 1970. Crabs from the East China Sea IV. Gymnopeura, Dromiacea and Oxystomata. J. Fac. Agricul., Kyushu Univ., 16(3): 193-235.

Received October 21, 2009 Accepted November 6, 2009 